\title{
Chapter 12 \\ Medicinal Properties in the Diet of Tibetan \\ Macaques at Mt. Huangshan: A Case \\ for Self-Medication
}

\author{
Michael A. Huffman, Bing-Hua Sun, and Jin-Hua Li
}

\subsection{Introduction}

Life history strategies include growth, maintenance, and reproduction (Gadgil and Bossert 1970), all of which are dependent upon a proper diet for metabolic functions. Animal feeding strategies are based on finding and consuming a balance of the most essential nutritional elements, carbohydrates, fats, proteins, trace elements, and vitamins, while at the same time avoiding the negative impacts of secondary metabolites in plants (Lambert 2011; Simpson et al. 2004). These secondary metabolites protect plants from predation by an array of insect and vertebrate herbivores that prey upon them by reducing palatability and digestibility (Freeland and Janzen 1974; Glander 1982; Rosenthal and Berenbaum 1992). Nonetheless, this does not always inhibit animals from ingesting such plants in tolerable amounts for purposes other than nutrition.

The idea that animals may ingest plants for their medicinal value was first suggested by Janzen (1978), based on a variety of anecdotal reports from the wild. The study of primate self-medication then began in earnest as a scientific discipline in the mid-to-late 1980s with observations of chimpanzees in the wild (see Huffman 2015). Nonetheless, it is widely documented that humans have traditionally seen animals as a source of knowledge about the use of plants for their medicinal value

M. A. Huffman (ه)

Primate Research Institute, Kyoto University, Kyoto, Japan

e-mail: huffman.michael.8n@kyoto-u.ac.jp

B.-H. Sun

School of Resources and Environmental Engineering, Anhui University, Hefei, Anhui, China

J.-H. Li

School of Resources and Environmental Engineering, Anhui University, Hefei, Anhui, China

International Collaborative Research Center for Huangshan Biodiversity and Tibetan Macaque Behavioral Ecology, Anhui, China

School of Life Sciences, Hefei Normal University, Hefei, Anhui, China

e-mail: jhli@ahu.edu.cn 
(Engel 2002; Huffman 1997, 2002, 2007). Humans can learn from watching sick wild primates, because we share the same evolutionary history, possess a common physiology, and have lived together under similar environmental conditions for much of our species' history. It has been argued that we have inherited many of the same ways to combat common diseases in the environment (Huffman 2016). Indeed, recent archeological and biochemical evidence supports the idea by showing that one of our closest extinct ancestors, Homo neanderthalensis, also used medicinal plants still widely in use today by modern humans (Hardy et al. 2012, 2013; Huffman 2016).

Self-medication research focuses on understanding how animals respond to illness and how these behaviors can be transmitted across generations (Huffman 1997). It has also been argued to be a bio-rational for the exploration and exploitation of novel secondary plant compounds and new insights into how they can be used for the management of health in humans and livestock (Huffman et al. 1998; Krief et al. 2005; Petroni et al. 2016). At the proximate level, self-medication may be driven by the necessity to maintain physiological homeostasis to stay in relatively good condition (Foitova et al. 2009; Forbey et al. 2009).

Currently, the majority of evidence for self-medication in animals comes from the study of how they deal with parasite or pathogen-induced illness (see Huffman 1997, 2011). While some parasitic infections likely go unnoticed, when homeostasis is disrupted or threatened, it is expected to be in the best interest of the host to actively respond in ways to alleviate discomfort. However, there is no reason why selfmedication should be limited to parasitosis, since animals are faced with a wide variety of health homeostatic challenges brought upon by such factors as reproductive events, climatic extremes, or other seasonal events (Carrai et al. 2003; Huffman 1997, 2011; Ndagurwa 2012). The ability of a species to defend itself against lifethreatening conditions provides a significant adaptive advantage and thus should be present throughout the entire animal kingdom.

In 1997, the concept of "medicinal foods" was formally introduced to primatology, adding the extra element of passive prevention of disease based on the presence of plants in the diet that contain noticeable bioactive, physiology-modifying properties, from which the animals ingesting them could potentially benefit (Huffman 1997). This term was borrowed from the human ethnopharmacological literature (Etkin 1996). For example, among the Hausa of Nigeria, 30\% of the wild plant food species they ingest are also used as medicine. Interestingly, of the species used by these people to treat symptoms of malaria, 89\% are also eaten as food (Etkin and Ross 1983). Many food items eaten by primates and other mammals have also been shown to contain a variety of secondary metabolites with medicinal properties (roughly 15-25\% of any population's food plant species list), suggesting that animals may benefit from the periodic ingestion, in small amounts of these plants (sifaka Propithecus verreauxi verreauxi, Carrai et al. 2003; gorillas Gorilla gorilla and G. beringei, Cousins and Huffman 2002; chimpanzees Pan troglodytes, Huffman 1997, 2003; Japanese macaques Macaca fuscata, Huffman and MacIntosh 2012; MacIntosh and Huffman 2010; various ungulate species, Mukherjee et al. 2011; lemurs Eulemur fulvus, Negre et al. 2006; wooly spider monkeys Brachyteles arachnoides, Petroni et al. 2016). The secondary compound rich content of some 
foods in the diet may play a significant role in the maintenance of health. Two examples associated with risks to parasite infection illustrate this point.

The medicinal diet of chimpanzees in the Mahale M group of Tanzania was examined (Huffman 1998) by conducting a database search using the African ethnomedicine literature. From 172 chimpanzee food species, 43 (22\%) items were found to be used to treat parasitic- or gastrointestinal-related illnesses by humans. It was also common for some species to have multiple ethnomedicinal uses. While not all 43 species may have been ingested by chimpanzees in such a way as to benefit from these potential medicinal properties, $33 \%$ (20/63) of the plant parts ingested (leaf and stem $=75 \%$, bark $15 \%$, seed $=5 \%$, fruit $=5 \%$ ) from 16 of these species corresponded to the parts utilized by humans specifically for the treatment of intestinal parasites and gastrointestinal illness.

The medicinal diet and parasite richness of ten Japanese macaque troops were examined (MacIntosh and Huffman 2010). The study troops were selected to represent the species entire distribution, ranging from the extreme cold temperate zone of Shimokita peninsula down to the subtropical island of Yakushima. A total of 1664 plant part items (range, 56-408) from 694 species were the target of an extensive literature search for potential antiparasitic activity in the diet. Of all these ingested items, 198 (from 135 species) were found to have reported antiparasitic properties. The proportion of these antiparasitic items ranged from 12 to $18 \%$ across these ten troops. A further 167 plant items (133 species) exhibited medicinal properties not related to parasitic infection or gastrointestinal symptoms. Because nematode species richness is negatively associated with latitude among Japanese macaques (Gotoh 2000), it was predicted that the proportion of antiparasitic items in their diets would also follow the same pattern (MacIntosh and Huffman 2010). A tendency was noted for the proportion of antiparasitic food items to decrease with increasing latitude, and a strong positive statistically significant relationship between the proportions of antiparasitic items ingested and nematode species richness was found. The proportion of medicinal items unrelated to parasite activity showed no such relationship with either latitude or with nematode species richness, supporting the hypothesis that the medicinal diet was somehow influenced by the degree of parasite pressure, relative species richness, and potentially parasite load.

From these and other studies noted above, a pattern is emerging, by which primates and other mammals incorporate certain food items with medicinal properties into their diet. In primates the information thus far shows a strong connection between medicinal food consumption and parasite infection and or reproductive events. Both factors present significant challenges to the survival and fitness of an individual. Knowing what immediate homeostasis challenges that impact individuals of a group can help to better understand how the medicinal components of their diet may work in an animal's favor.

Currently, limited details are available about health and diseases affecting Tibetan macaques (Macaca thibetana). In a case study of the troop fission event of YA and YB, the sudden mass death of 17 individuals over a 1-week period was mentioned (Li et al. 1996). Disease was suggested to be responsible, but no diagnosis was 
given. The speed and widespread effect could be suggestive of an aggressive viral infection, whose virulence was perhaps exacerbated by high stress levels.

Zhu et al. (2012) report the presence of nine intestinal nematode species in Tibetan macaques, with special note of the zoonotic Gongylonema pulchrum, having the highest prevalence rate of $31.58 \%$, followed by Trichuris trichiura $(25.00 \%)$, Oesophagostomum apiostomum (23.68\%), Ancylostoma duodenale (hookworm) (14.47\%), Trichostrongylus sp. (13.16\%), and other species of lower prevalence. These parasites are known to be responsible for mild to severe pathogenesis (Brack 1987). Among them, O. apiostomum is noted to be responsible for perhaps the severest pathogenesis, in particular among previously infected (pre-immunized) individuals. In these cases, encysted larvae are trapped in the intestinal mucosa by elevated immune response, causing the larvae to die inside the cyst, leading to inflammation, necrosis, and hemorrhaging, and in severe cases leading to secondary bacterial infections, necrosis of the intestinal mucosa, weight loss, weakness, and mortality (Brack 2008). O. stephanostomum, a sister species infecting chimpanzees, and other great apes, is equally pathogenic and is associated with self-medicative behaviors used in the therapeutic treatment with Vernonia amygdalina by chimpanzees with high-level infections during the rainy season (Huffman 1997; Huffman and Caton 2001). Furthermore, evidence for the possible role of medicinal foods for controlling O. stephanostomum and other infections has also been suggested (Huffman 1997).

While more work is clearly needed to understand the different factors affecting the homeostasis of Tibetan macaques (Macaca thibetana) possibly leading to selfmedication, we take this opportunity to evaluate their diet for its potential medicinal value. We predict there is a proportion of the diet containing plants with medicinal value, and it is our goal to highlight that potential for future research, in order to better understand the role of diet in health maintenance and self-medication in Tibetan macaques.

\subsection{Materials and Methods}

The subjects of this investigation are Tibetan macaques living in the Valley of the Monkeys ( $\left.118^{\circ} 11^{\prime} \mathrm{W}, 30^{\circ} 29^{\prime} \mathrm{N}\right)$, Mt. Huangshan, Anhui Province, China. The site is situated at an elevation of approximately $1840 \mathrm{~m}$ above sea level, and the year is divided into four seasons: winter (December to February), spring (March to May), summer (June to August), and autumn (September to November). Average temperatures range from around $0{ }^{\circ} \mathrm{C}$ in mid-winter to around $25^{\circ} \mathrm{C}$ in summer (Fig. 12.1). Peaks in rainfall occur during the months of May through July, tapering off in autumn and winter. (Further details of the study site are presented in other chapters of this book.)

Analysis of the diet of Yulinkeng 1 (YA1) troop was based on a plant food list previously published by You et al. (2013). At the time of that study, the troop consisted of 28 individuals: 12 adults ( 4 males, 8 females), 10 juveniles ( 6 males, 

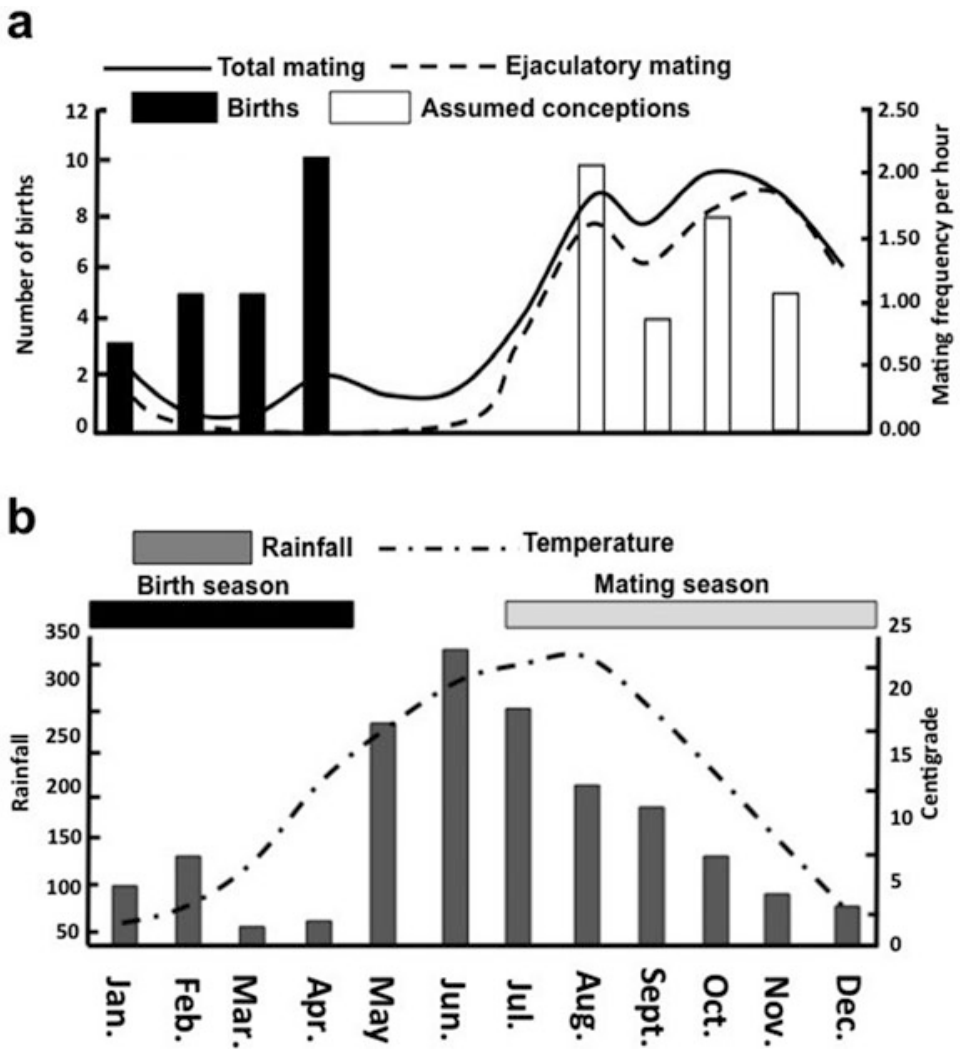

Fig. 12.1 Annual distribution of mating, births, and conceptions of Tibetan macaques (a) and monthly rainfall and temperature (b) at Mt. Huangshan. These figures were redrawn, modified, and combined from previously published material for illustrative purposes ( $\mathrm{Li}$ et al. 2005). The meteorological data presented here is the average of 10 years (1983-1992)

4 females), and 6 infants (5 males, 1 female). Direct observations of the troop's feeding behavior in the rugged terrain of Mt. Huangshan are challenging, and to overcome these difficulties, the investigators produced a food list based on the analysis of 81 fecal samples collected over 10-day blocks, one block each during winter, spring, summer, and autumn between November 2011 and October 2012 (You et al. 2013). While the study covered just 1 year, it provides an important basis for an evaluation of the medicinal potential of food items ingested by the troop during that period.

The method used to quantify the relative contribution of each plant species (part) took a microhistopathological approach to identify ingested food remains in the feces. The method is a validated, well-established, procedure developed by Sparks and Malechek (1968) and has been used to quantify the botanical composition of diets in a variety of free-ranging, sometimes difficult to directly monitor, domestic and wild animals in their natural habitats (e.g., mule deer Odocoileus hemionus, 
Anthony and Smith 1974; musk deer Moschus leucogaster, Green 1987; domestic goats Capra aegagrus hircus, Mellado et al. 1991; cattle Bos taurus, sheep Ovis aries, Angora goats, Alipayo et al. 1992; wild turkeys Meleagris gallopavo, Rumble and Anderson 1993; Yunnan snub-nosed monkeys Rhinopithecus bieti).

The method requires the assembly of histopathological plant tissue reference key slides prepared from identified plant species in the habitat. These keys are then used to microscopically identify plant parts in the feces based on each species' unique cell tissue structure characteristics (see Ahmed et al. 2015). At Huangshan, a total of 224 plant species (73 families) in the habitat were identified and histopathological reference keys were made (You et al. 2013). They calculated the relative density (RD) of each species (and family) present in the feces using the following formula, where:

$\mathrm{RD}=$ the density of a plant particle/the total density of all plant particles $\times 100$.

We evaluated the medicinal properties of each plant species in the resulting list for medicinal value using online database sources [Traditional Chinese Medicinal Plants (Duke and Ayensu 1985); Find Me A Cure (2018); Herbpathy Data Base (2018); Plants For A Future Data Base (1996-2012); World Agroforestry Data Base (2018)], followed up with Google Scholar article searches by plant species and/or active compound name, focusing on the plant items (leave, fruits, stems, bark, roots, flowers) ingested by YA1 troop members.

Data sorting and descriptive statistics were carried out using Microsoft ${ }^{\circledR}$ Excel $^{\circledR}$ for Mac 2011 (Ver. 14.7.2.). Statistical analyses for chi-square were carried out using an online calculator: https://www.socscistatistics.com/tests/chisquare2/ Default2.aspx. Statistical significance was set at 0.05 .

\subsection{Results and Discussion}

\subsubsection{Plant Food Species and Their Relative Density (RD) Values}

To put the medicinal foods ingested by members of the troop into perspective, we first describe the overall trends of their feeding habits as revealed in the dietary analysis. The plant food species consumed by YA1 troop members are listed in descending order of RD by family and species in Table 12.1. The species RD values are summarized seasonally, with each season totaling $100 \%$. Fifty species (61 different items, 26 families) from across the entire study period were analyzed here. Of the 61 items ingested, leaves accounted for 78\%, by far the largest proportion of plant parts found, followed by fruits $11 \%$, stems $3 \%$, buds $2 \%$, seeds $2 \%$, young shoots $2 \%$, and flowers $2 \%$. 
Table 12.1 Plant food species, part(s) eaten, and seasonal variation of use in the YA1 troop of Tibetan macaques at Mt. Huangshan

\begin{tabular}{|c|c|c|c|c|c|}
\hline \multirow[b]{2}{*}{ Family and species } & \multirow{2}{*}{$\begin{array}{l}\text { Parts } \\
\text { Consumed }\end{array}$} & \multicolumn{4}{|c|}{ Relative density (RD) } \\
\hline & & Winter & Spring & Summer & Autumn \\
\hline \multicolumn{6}{|l|}{ Fagaceae } \\
\hline Castanpopsis eyrei (Champion ex Bentham) Tutcher & Leaf, fruit & $14.78 \%$ & $9.17 \%$ & $10.49 \%$ & $14.48 \%$ \\
\hline Lithocarpus glaber (Thunb.) Nakai & Leaf, fruit & $6.60 \%$ & $6.62 \%$ & $4.27 \%$ & $6.46 \%$ \\
\hline Quercus myrsinaefolia Blume & Leaf, fruit & $6.06 \%$ & $7.38 \%$ & $7.41 \%$ & $9.37 \%$ \\
\hline Quercus glauca Thunb. & Leaf, fruit & $2.50 \%$ & $3.12 \%$ & $5.05 \%$ & $7.69 \%$ \\
\hline Quercus glandulifera Blume & Leaf, fruit & 0 & $1.22 \%$ & $5.41 \%$ & $2.08 \%$ \\
\hline Quercus aliena Blume & Leaf, fruit & 0 & 0 & 0 & $0.60 \%$ \\
\hline \multicolumn{6}{|l|}{ Lauraceae } \\
\hline Litsea coreana $\mathrm{H}$. Léveillé & Leaf & $12.09 \%$ & $8.08 \%$ & $9.55 \%$ & $4.66 \%$ \\
\hline Machilus leptophylla Handel-Mazzetti & Leaf & $4.53 \%$ & $2.53 \%$ & $6.84 \%$ & $7.11 \%$ \\
\hline Phoebe sheareri (Hemsley) Gamble in Sargent & Leaf & $4.04 \%$ & $2.88 \%$ & $5.12 \%$ & $5.55 \%$ \\
\hline Machilus thunbergii Siebold \& Zuccarini & Leaf, bud & $0.66 \%$ & $13.50 \%$ & $2.20 \%$ & $1.68 \%$ \\
\hline Lindera aggregata (Sims) Kostermans & Leaf & 0 & $0.17 \%$ & $0.30 \%$ & $0.07 \%$ \\
\hline \multicolumn{6}{|l|}{ Poaceae } \\
\hline Zea mays L. (corn) & Seed & $8.94 \%$ & $7.13 \%$ & $6.76 \%$ & $4.06 \%$ \\
\hline Carex tristachya Thunberg in Murray & Leaf & $2.08 \%$ & $2.82 \%$ & $4.78 \%$ & $1.37 \%$ \\
\hline bamboo & Young shoots & $3.47 \%$ & $2.88 \%$ & $2.65 \%$ & $2.16 \%$ \\
\hline \multicolumn{6}{|l|}{ Ericaceae } \\
\hline Rhododendron ovatum (Lindley) Planchon ex Maximowicz & Leaf & $3.37 \%$ & $3.97 \%$ & $1.54 \%$ & $2.65 \%$ \\
\hline Vaccinium bracteatum Thunberg in Murray & Leaf & $2.05 \%$ & $1.34 \%$ & $2 \%$ & $1.06 \%$ \\
\hline Rhododendron sp. & Leaf, flower & $1.27 \%$ & $0.87 \%$ & $2.07 \%$ & $1.22 \%$ \\
\hline Vaccinium mandarinorum Diels & Leaf & & $1.40 \%$ & $1.30 \%$ & $0.68 \%$ \\
\hline
\end{tabular}

Hamamelidaceae

\begin{tabular}{|c|c|c|c|c|c|}
\hline Loropetalum chinense (R. Brown) Oliver & Leaf, stem & $5.18 \%$ & $4.09 \%$ & $3.51 \%$ & $2.81 \%$ \\
\hline Distylium myricoides Hemsley & Leaf, stem & $1.31 \%$ & $0.35 \%$ & $1.26 \%$ & $1.61 \%$ \\
\hline Liquidambar formosana Hance & Leaf & 0 & $0.23 \%$ & 0 & 0 \\
\hline \multicolumn{6}{|l|}{ Theaceae } \\
\hline Camellia cuspidata (Kochs) H. J. Veitch & Leaf & $5.18 \%$ & $4.76 \%$ & $2.84 \%$ & $3.81 \%$ \\
\hline Eurya alata Kobuski & Leaf & $1.09 \%$ & $0.64 \%$ & $1.44 \%$ & $0.37 \%$ \\
\hline Eurya muricata Dunn & Leaf & 0 & $0.58 \%$ & 0 & $1.45 \%$ \\
\hline Eurya nitida Korthals & Leaf & 0 & $0.23 \%$ & $3.58 \%$ & $2.08 \%$ \\
\hline
\end{tabular}


Table 12.1 (continued)

\begin{tabular}{|c|c|c|c|c|c|}
\hline \multirow[b]{2}{*}{ Family and species } & \multirow{2}{*}{$\begin{array}{l}\text { Parts } \\
\text { Consumed }\end{array}$} & \multicolumn{4}{|c|}{ Relative density (RD) } \\
\hline & & Winter & Spring & Summer & Autumn \\
\hline \multicolumn{6}{|l|}{ Leguminosae } \\
\hline Millettia dielsiana Harms. ex Diels. & Leaf & $2.36 \%$ & $2.53 \%$ & $1.88 \%$ & $1.84 \%$ \\
\hline Lespedeza bicolor Turczaninow & Leaf & 0 & $0.35 \%$ & $1.44 \%$ & 0 \\
\hline \multicolumn{6}{|l|}{ Saxifragaceae } \\
\hline Itea omeiensis C. K. Schneider in Sargent & Leaf & $2.09 \%$ & $1.34 \%$ & $1.09 \%$ & $0.22 \%$ \\
\hline \multicolumn{6}{|l|}{ Taxaceae } \\
\hline Torreya grandis Fortune ex Lindley & Leaf & $1.37 \%$ & $0.64 \%$ & 0 & 0 \\
\hline \multicolumn{6}{|l|}{ Aquifoliaceae } \\
\hline Ilex purpurea Hassk. & Leaf & $0.52 \%$ & $0.29 \%$ & & $0.68 \%$ \\
\hline \multicolumn{6}{|l|}{ Myrtaceae } \\
\hline Syzygium buxifolium Hooker \& Arnott & Leaf & $0.49 \%$ & $0.06 \%$ & $0.75 \%$ & $0.15 \%$ \\
\hline \multicolumn{6}{|l|}{ Cephalotaxaceae } \\
\hline Cephalotaxus fortunei Hooker & Leaf & $0.40 \%$ & 0 & 0 & 0 \\
\hline \multicolumn{6}{|l|}{ Taxodiaceae } \\
\hline Cunninghamia lanceolata (Lambert) Hooker & Leaf, fruit & $7.60 \%$ & $0.11 \%$ & $0.91 \%$ & $2.08 \%$ \\
\hline \multicolumn{6}{|l|}{ Ranunculaceae } \\
\hline Thalictrum aquilegifolium $\mathrm{L}$. & Leaf & 0 & $0.11 \%$ & $0.53 \%$ & 0 \\
\hline \multicolumn{6}{|l|}{ Anacardiaceae } \\
\hline Toxicodenddron sylvestre (Siebold \& Zucc.) Kuntze & Leaf & 0 & $0.17 \%$ & $0.83 \%$ & $0.30 \%$ \\
\hline \multicolumn{6}{|l|}{ Araliaceae } \\
\hline Hedera nepalensis var. sinensis (Tobler) Rehder & Leaf & 0 & $0.29 \%$ & 0 & $1.76 \%$ \\
\hline \multicolumn{6}{|l|}{ Styracaceae } \\
\hline Pterostyrax corymbosus Siebold \& Zuccarini & Leaf & 0 & $0.23 \%$ & 0 & 0 \\
\hline \multicolumn{6}{|l|}{ Tiliaceae } \\
\hline Tilia oliveri Szyszyłowicz & Leaf & 0 & $0.52 \%$ & $1.13 \%$ & 0 \\
\hline \multicolumn{6}{|l|}{ Berberidaceae } \\
\hline Epimedium davidii Franchet & Leaf & 0 & $0.23 \%$ & 0 & 0 \\
\hline \multicolumn{6}{|l|}{ Gesneriaceae } \\
\hline Conandron ramondioides Siebold \& Zuccarini & Leaf & 0 & 0 & 0 & $0.30 \%$ \\
\hline
\end{tabular}


Table 12.1 (continued)

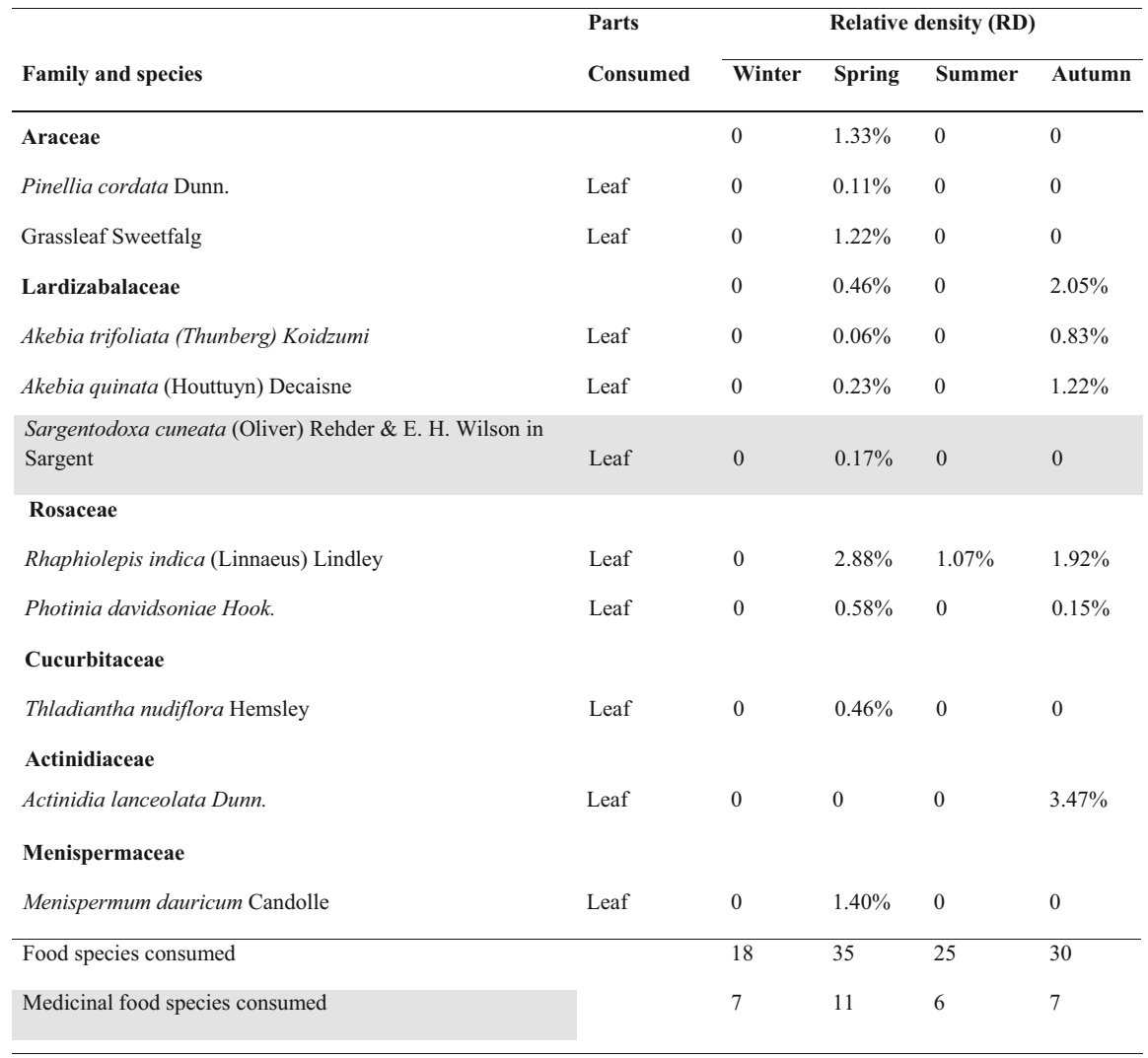

List is modified from You et al. (2013). RD percentages are summarized per season. $n=50$ species Medicinal food species consumed are highlighted in grey

Seasonal variation was noted in the number of plant species ingested from their total repertoire (Fig. 12.2), but these differences were not statistically significant $\left(\chi^{2}=6.93, d f=3, p>0.05\right)$. The largest number of species consumed was in spring $(n=46)$, followed by autumn $(n=37)$, summer $(n=31)$, and winter $(n=25)$. With the exception of one species, Cunninghamia lanceolata (Taxodiaceae) whose leaves and fruit were both consumed, all ingested fruit items (nuts, acorns) come from the Fagaceae family. Combined, use of leaf and fruit items in this family had the highest $\mathrm{RD}$ values of all plant food species identified, and none of these were classified as medicinal foods. The highest of these RD values were recorded in autumn and summer and involved the consumption of ripening and fallen ripe fruits, the main food items sought after in these two seasons. The second largest RD value family was Lauraceae, with five species, whose leaves and buds were consumed. Only one of the five species in this family, Litsea coreana, was classified as a medicinal food. 
Fig. 12.2 Seasonal variation in the ingestion of food and medicinal food species (a) and average RD values of food and medicinal food species by YA1 troop. (b) Mean RD values calculated from individual species RD values per season presented in Table 12.1. Data derived from You et al. (2013)

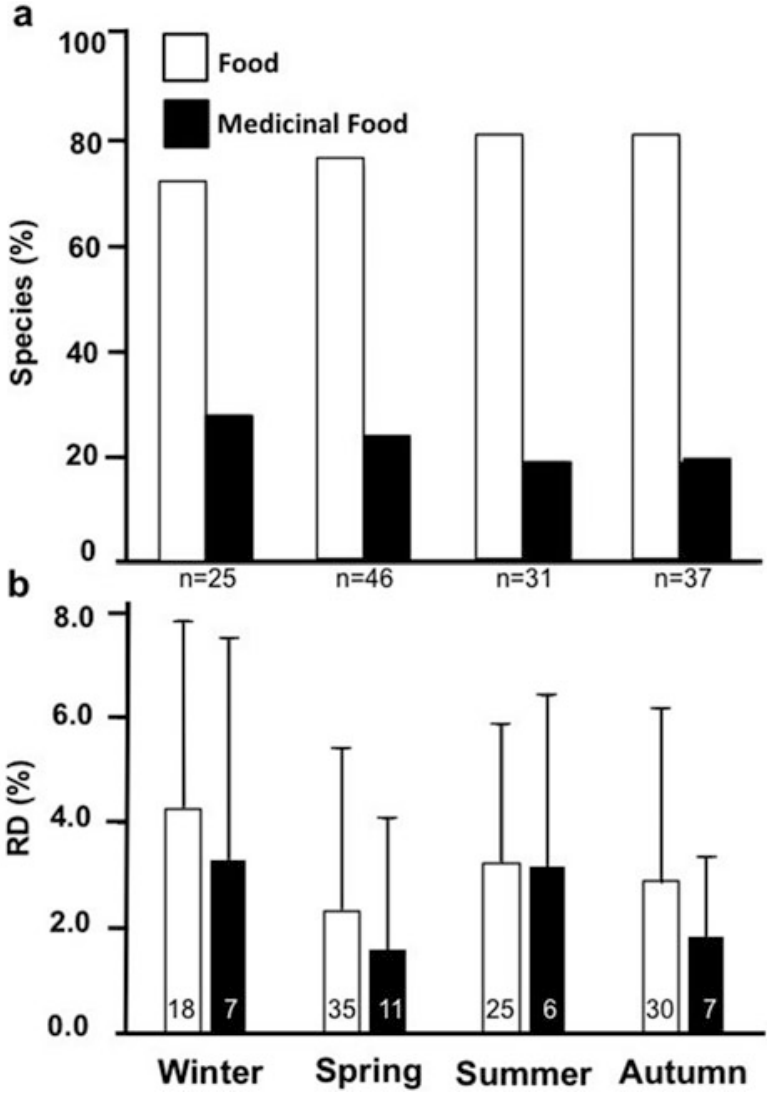

\subsubsection{Medicinal Foods in the Diet}

Across the entire study period, 12 species (13 items: 12 leaves, 1 stem) in the diet had notable medicinal activity in the plant part ingested by members of YA1 troop (Table 12.1). Our literature search revealed an array of pharmacological properties of high medicinal value including antiparasitic, antiprotozoal, antibacterial, antifungal, antiviral, anti-dysentery, anti-enteritis, anticancer (antitumor), antiinflammation, antirheumatic, antidiabetic, cardiovascular protective, neuroprotective, osteoprotective, reproductive stimulant, antidepressant, immunosuppressant, and diaphoretic; treatment for ulcers, wounds, skin disease, weakness, and dizziness; and other health-protecting and health-promoting activities. Associated with these activities are a variety of physiologically active secondary plant metabolites (Appendix).

The following are detailed descriptions of the 12 plant species' seasonality of use, life form, pharmacological properties, and prescribed uses by humans. 
Cephalotaxus fortunei (Leaf, Used in Winter) Evergreen Tree Abietane diterpenoids synthesized by suspension-cultured cells displayed a wide spectrum of biological activities including antiparasitic, antibacterial, antifungal, and antiviral properties. These compounds were found to be effective against pathogens such as Mycobacterium tuberculosis and Staphylococcus aureus, including methicillinresistant (MRSA) strains and biofilm infection of S. aureus (Neto et al. 2015). Abietane diterpenes isolated from aerial parts of Plectranthus barbatus showed remarkable activity with acceptable selectivity against the blood parasites Plasmodium falciparum (malaria) and Trypanosoma brucei (sleeping sickness in animals). Nonspecific antiprotozoal activity was also detected and is likely due to the compound's high cytotoxicity (Mothana et al. 2014). This plant also demonstrates significant anticancer activity (Duke and Ayensu 1985).

Epimedium davidii (Leaf Used in Spring) Perennial Herb Compounds isolated from the leaves include Icariside II (Baohuoside I) and Baohuoside II, III, V, and VI (Ma et al. 2011). These compounds possess therapeutic activities such as osteoprotective effect, neuroprotective effect, cardiovascular protective effect, anticancer effect, anti-inflammation effect, immunoprotective effect, and enhancement of reproductive function (sexual health for males and females) (Li et al. 2015). Treatment with the compound icariin is reported to significantly increase epididymal sperm counts and testosterone levels of male rats (Chen et al. 2014) and significantly increases erectile function in castrated Wistar rats by increasing the percentage of smooth muscle and inducible nitric oxide synthase in the corpus cavernosum (Liu et al. 2005). Active ingredients administered at a dose of $5 \mathrm{~g} / \mathrm{kg}^{-1}$ with an ig volume of $5 \mathrm{~mL} \mathrm{~kg}^{-1}$ alleviated the impact of high-intensity exercise on serum testosterone, maintaining it at normal physiological levels. It can also promote protein synthesis, inhibit degradation of amino acid and protein, and increase hemoglobin and glycogen reserves in rats receiving exercise training (Zhou et al. 2013).

A series of tests on rats and mice using icariin have also reported significant stress reduction and antidepressant properties via downregulation of glucocorticoid receptor activity and regulation of hippocampal neuroinflammation are associated with this plant species (Pan et al. 2010; Wu et al. 2011; Gong et al. 2016). The leaves of this species are also noted for their anticancer activity (Frohne and Pfänder 1984), immunosuppressive action, and inhibitory properties of lymphocyte activation (Ma et al. 2004).

\section{Hedera nepalensis (Leaf Used in Spring and Autumn), Evergreen Climber or}

Creeper Vine The leaves and berries are reported to have cathartic, diaphoretic, and stimulant properties. A decoction is used to treat skin diseases. Significant cancer chemo-preventative and cytotoxic properties have been demonstrated (Jafri et al. 2016). It is also reported to be an important folk medicine for the treatment of diabetes. No specific mention of $H$. nepalensis is given, but a closely related species Hedera helix is relevant to this discussion, as it has a similar chemical makeup and has been noted to be poisonous in large doses, but the leaves are eaten without observed side effects in wild mammals. Leaves contain hederagenin, a saponic glycoside, which can cause gastrointestinal nervous system disturbances, breathing difficulties, and coma if eaten in large amounts (Plants For A Future.com). 
Ilex purpurea (Leaf Used in Winter, Spring, and Autumn) Evergreen Tree The plant is considered to be one of the 50 fundamental herbs in Chinese medicine. It is reported to have antitumor properties, and an extract of the leaves is made into a solution and used for treating burns and ulcers in the lower extremities. The ashes of burnt leaves are used as a dressing for skin ailments and infected wounds (Duke and Ayensu 1985).

Lespedeza bicolor (Leaf Used in Spring and Summer) Deciduous Shrub Leaves contain flavonoids, alkaloids, terpenes, organic acids, and stigmasterols. Potential for antioxidant, anticancer, and antibacterial activity is also noted (Ullah 2017) and is traditionally used for coughs and colds, kidney and urethra problems, fever, headache, weakness, and dizziness (Chang et al. 2017).

Liquidambar formosana (Leaf Used in Spring) Deciduous Tree The leaves are used in the treatment of cancerous growths (Duke and Ayensu 1985).

Litsea coreana (Leaf Used Year Round) Evergreen Tree Exhibits notable bioactivities, such as hepatoprotection, hyperglycemia, anti-inflammation, antioxidation, and antibacterial properties through multiple molecular mechanisms. These compounds augment immunoglobulin $\mathrm{M}$ and $\mathrm{G}$ values and show significant inhibitory effects on the pathogens Bacillus anthracis, Proteusbacillus vulgaris, Staphylococcus aureus, and Bacillus subtilis. Anti-HSV-1 activity and anti-gastric carcinoma and anti-colon carcinoma HT-29 activity have been reported. Leaves contain polysaccharides, polyphenols, essential oils, and numerous flavonoids (Jia et al. 2017).

\section{Loropetalum chinense (Leaf, Stem Used Year Round) Evergreen Woody} Shrub The leaves are crushed and pulverized for external application on wounds (Find Me A Cure.com), while a decoction of the whole plant is used to treat coughing in tuberculosis patients and is a treatment against dysentery and enteritis. This species also promotes wound healing and possesses antibacterial, antiinflammatory, antioxidant, and antitumoral activity, as well as adjusts fat metabolism, and protects from cardiovascular disease (Zhou et al. 2014).

Millettia dielsiana (Leaf Used Year Round) Deciduous Shrub A decoction or tincture of leaves is used to treat hookworm, roundworm (nematodes), and filarial infections and is a treatment for amenorrhea, metrorrhagia, anemia, traumatic injuries, and rheumatoid arthritis (Anonymous 1977; Yeung 1985). Stem extracts exhibit anti-enterovirus activity and is effective against Coxsackie virus B3, Coxsackie virus B5, Poliovirus I, Echovirus 9, and Echovirus 29 (Guo et al. 2006). It also aids in the prevention of cardiovascular and cerebrovascular disease. It possesses high antioxidant activity (Gan et al. 2010). Seven isoflavones have been isolated from the stem and identified as 6-ethoxyca lpogonium isoflavone A, durmillone, ichthynone, jamaicin, toxicaro 1 isoflavone, barbigerone, and genistein (Gong et al. 2007).

Sargentodoxa cuneata (Leaf Used in Spring) Deciduous Climbing Shrub The stem is anthelmintic, antibacterial, antirheumatic, carminative, diuretic, and tonic (Usher 1974; Anonymous 1977; Yeung 1985; Duke and Ayensu 1985). The mashed leaves are plastered onto sores (Duke and Ayensu 1985). A decoction or tincture is 
used in the treatment of anemia, traumatic injuries, rheumatoid arthritis, hookworm disease, roundworm, and filariasis (Anonymous 1977; Yeung 1985). Stem extracts exhibited anti-enterovirus activity against anti-Coxsackie virus B3, Coxsackie virus B5, Polio virus I, Echovirus 9, and Echovirus 29 (Guo et al. 2006).

Syzygium buxifolium (Leaf Used Year Round) Evergreen Shrub The juice of macerated leaves are taken to reduce fever (Duke and Ayensu 1985). Leaf powder is rubbed on the skin of smallpox patients for its cooling effect (World Agroforestry. org).

Vaccinium bracteatum (Leaf Used Year Round) Evergreen Shrub Leaves contain isoorientin, orientin, vitexin, isovitexin, isoquercitrin, quercetin-3-O- $\alpha$-Lrhamnoside, and chrysoeriol-7-O- $\beta$-D-glucopyranoside. Radical scavenging activity and protection against $\mathrm{KBrO} 3$-mediated kidney damage have been demonstrated (Zhang et al. 2014a, b). Anticancer and anti-inflammatory activity was demonstrated (Landa et al. 2014).

\subsubsection{Seasonality of Medicinal Food Ingestion}

In total, $76 \%$ of the 50 species (61 food items from 26 families) reported in YA1 troop's diet showed no evidence of significant toxicity or pharmacological activity, supporting the assumption that most plants in the diet are indeed selected for their nutritional value. However, the remaining $24 \%(n=12)$ of the species are considered medicinal foods, with potential health-promoting properties.

There was no statistically significant seasonal difference in the number of medicinal foods in the diet $\left(\chi^{2}=0.9371, p>0.05, d f=3\right.$; Fig. 12.2). However, more medicinal food species were consumed in winter (28\%) and spring $(24 \%)$ and then summer $(19 \%)$ or autumn (19\%). All the consumed medicinal plant items were leaves. Seven of these species are evergreen trees, shrubs, or creepers, so leaves of these species are available year-round. The remaining five species were deciduous trees or shrubs, with leaves only in spring and summer months. These results suggest a broad based potential for access to medicinal food across the year. While the number of potential medicinal species ingested is not significantly different across seasons, the particular species ingested varied between seasons in some cases and present some interesting patterns related to their possible seasonal benefits. The three following categories of health concern extracted from our analysis provide some important areas for future investigation.

\subsubsection{Antiparasitic Properties}

Previous reports of medicinal food ingestion and therapeutic self-medication in response to parasite infections point out the relationship between seasonality of 
reinfection and plant ingestion as evidence for the context of plant use (Huffman et al. 1997, 1998). While no clear-cut seasonal trend for medicinal food ingestion was apparent in the YA1 troop diet, the relationship between medicinal properties of five specific medicinal food species and their seasonality of use provides information for future detailed investigation. C. fortunei, L. bicolor, L. coreana, L. chinese, and $S$. cuneata are reported to possess significant broad-spectrum antiparasitic, antibacterial, and antiviral activity. One of the highest RD values of all medicinal foods was assigned to $L$. coreana $(\mathrm{RD}=12.09 \%)$ consumption in winter. However, two of the most intriguing medicinal food candidates with wide-spectrum antiparasitic properties are $C$. fortunei and $S$. cuneata, even though both had low $\mathrm{RD}$ values $(0.40$ and 0.17 , respectively). Ingestion was restricted to winter in the former and spring in the later.

Winter and spring, the mating and birth seasons, respectively, could be potentially key seasons for investigating the parasite infection status of individuals before and after the ingestion of these plant species. One of the three zoonotic parasites identified in YA1 troop is O. apiostomum (Zhu et al. 2012). Infection in Japanese macaques by $O$. apiostomum occurs more frequently during winter months (MacIntosh et al. 2010), and self-medication in response to a sister species, O. stephanostomum, occurs in chimpanzees (Huffman 1997). The reduction of worm burden and temporary relief from related gastrointestinal upset has been linked to the ingestion of the bitter pith of V. amygdalina (Huffman et al. 1993, 1996a). In vitro pharmacological assays of $V$. amygdalina demonstrate a broad range of antiparasitic activities (e.g., Ohigashi et al. 1994; Oyeyemi et al. 2018).

For respiratory viruses, seasonal changes in humidity improve viral survival and increase opportunities for infection (Altizer et al. 2006). A general survey of disease prevalence in YA1 troop is necessary to provide further insights about the ecology of infection dynamics that could lead to important links with their medicinal diet. L. bicolor is associated with possible respiratory health, and a number of other species could inhibit respiratory viruses from establishment (Chang et al. 2017).

\subsubsection{Reproductive Modulation}

Throughout history, humans have utilized a number of plant hormones to suppress or enhance their reproductive and sexual activity (Lewis and Elvin-Lewis 1977). The reproductive behavior of male and female Tibetan macaques has been studied from a variety of perspectives including endocrinology, behavior, and seasonal variation (e.g., Li et al. 2005; Xia et al. 2018; Zhao 1993). Tibetan macaques at Mt. Huangshan exhibit high levels of sexuality inside and sometimes outside of the mating season (Li et al. 2007, see Fig. 12.2 above; Xia et al. 2010). Could there be something in the diet that stimulates or enhances Tibetan macaque sexual behavior?

One medicinal food consumed by YA1 troop in particular deserves attention in this respect. Used as an aphrodisiac in Chinese traditional medicine, E. davidii is 
known as horny goat weed or rowdy lamb herb (Ma et al. 2011), suggesting an origin for the use of this plant from watching the behavior of animals. Experimental studies have demonstrated significant enhancement of reproductive function, including increased sperm count, testosterone levels, and enhanced erectile function in rats (Chen et al. 2014; Li et al. 2015; Liu et al. 2005), but ingestion of E. davidii by macaques at Mt. Huangshan is limited to spring, the birth season of this troop. The seasonal timing of the consumption of this plant is preceded by a decline in ejaculatory mating frequency at the end of the mating season in late winter. For a few months in spring, non-ejaculatory mating continues at low levels with a slight peak around April (Fig. 12.1). Could the ingestion of this plant be having some effect on their reproductive activity? There is precedence in the literature to believe there might be.

Ingestion of plant hormones by animals has been found to have a number of other influences on reproductive behavior (e.g., Berger et al. 1977; Starker 1976; Sadlier 1969). Wasserman et al. (2012) report the seasonal influence of estrogenic plant consumption on hormonal and behavioral fluctuations in red colobus monkeys (Procolobus rufomitratus) in Uganda. Peaks in the consumption of young leaves (Millettia dura) with high estrogen levels coinciding with both fecal estradiol and cortisol levels in the feces. This was associated with increased levels of both copulation and aggressive interactions. In a study by Whitten (1983), the timing of onset, duration, and ending of seasonal mating behavior in female vervet monkeys (Cercopithecus aethiops) were closely correlated with the availability and ingestion of the flowers of Acacia elatior (Mimosaceae). Later Garey et al. (1992) analyzed the flowers of this species and found them to be estrogenic. Garey and colleagues determined that the amount of flowers consumed by vervet monkeys could provide adequate exogenous estrogen to stimulate the onset of mating activity. Sargentodoxa cuneata is only ingested during the spring birth season and has been found to assist in menstrual regulation among people, as a prophylactic against amenorrhea or metrorrhagia (Anonymous 1977; Yeung 1985). Therefore, including this species in the diet could have some sex steroid-like properties that have a role in modifying female reproductive status after birth.

Phytoestrogens present in the diet of many primates have been proposed to affect birth spacing, influence the sex of offspring, and regulate fertility. Glander (1980) proposed that inter-annual variation in birth spacing of howler monkeys (Alouatta palliata) was due to inter-annual variation in food quality. That is births were concentrated seasonally in years when secondary compound concentration in plant foods were low (high food quality) and spread across the year when concentrations were high (low food quality).

An in-depth examination of sex and reproduction in the Gombe chimpanzees by Wallis $(1995,1997)$ noted significant seasonal patterns, and multiple reproductive parameters including conception, anogenital swelling, infant mortality, and fertility. Wallis proposed that intensive foraging on seasonally available plant foods containing phytoestrogens mediate these fertility factor (Wallis 1992, 1994, 1997). 
Hence, both male and female Tibetan macaque reproductive biology and behavior might be influenced by the inclusion in the diet of plants that have been shown in other species to influence reproductive hormones.

\subsubsection{Stress Reduction}

Stress disrupts health homeostasis, affecting reproductive function, overall health, and well-being of animals. Stress can be induced by both environmental and social factors, leading to physiological and behavioral imbalances (e.g., Takeshita et al. 2013, 2014; Wooddell et al. 2016). For example, primates living in seasonally cold habitats have a number of behavioral means for ameliorating cold stress, such as staying warm by sleeping and resting site selection, huddling, and, in one unique case, taking therapeutic hot spring baths (e.g., Hori et al. 1977; Zhang and Watanabe 2007; Kelley et al. 2016; Takeshita et al. 2018).

For stress induced by social interactions relating to social instability, dominance interactions, intergroup encounters, competition for food or mates, etc., affiliative behaviors such as grooming, reconciliation, consolation, and nonreproductive sexual behavior have been reported to be mechanisms of physiological reduction of stress in socially living species. Primates in particular have received wide attention (e.g., Aureli et al. 2002; Berry and Kaufer 2015; Carter et al. 2008; Fraser et al. 2008).

Tibetan macaques are classified as having a despotic, strongly linear, dominance style (Berman et al. 2004). They are well known for their kin-biased affiliation, tolerance, post-conflict reconciliation, nonreproductive mating, and the use of infants as a buffer to reduce tension between adults: "bridging" behavior (e.g., Bauer et al. 2014; Berman et al. 2004, 2007; Li et al. 2007; Ogawa 1995a, b). This suite of behaviors is linked to stress reduction through conflict buffering, suggestive of an undercurrent of social stress in their daily lives. Schenepel (2015) recorded high levels of agonistic and submissive behaviors around the provisioning area of YA1 troop compared to non-provision areas in the forest. Within the context of our study, we pose the question: "Do Tibetan macaques also have a dietary choice that aids in stress reduction?"

E. davidii is a prime candidate. Experimental evidence from several studies on hormonal and behavioral stress amelioration has been reported in relation to the administration of icariin, a major flavonoid isolated from E. davidii, in stressinduced rats and mice (Pan et al. 2010; Wu et al. 2011; Liu et al. 2015; Gong et al. 2016). Wu et al. (2011) demonstrated that icariin markedly decreased stressinduced downregulation of glucocorticoid receptors in mice subjected to "social defeat" by conspecifics. The compound also displays antidepressant activity and is used in Chinese traditional medicine for this purpose.

To the best of our knowledge, a dietary strategy for stress reduction has not yet received attention in the animal self-medication literature. Further investigation of the context of stress and the ingestion of plants like E. davidii may allow us to expand our knowledge of the role of diet in this area as well (Table 12.2). 
Table 12.2 Medicinal properties of the 12 candidate "medicinal foods" in the diet of YA1 troop of Tibetan macaques at Mt. Huangshan

\begin{tabular}{|c|c|}
\hline $\begin{array}{l}\text { Species (part ingested) [season } \\
\text { of use] form }\end{array}$ & $\begin{array}{l}\text { Medicinal properties (see text for references and further } \\
\text { details) }\end{array}$ \\
\hline $\begin{array}{l}\text { Cephalotaxus fortunei } \\
\text { (leaf) } \\
\text { [winter] evergreen, tree }\end{array}$ & $\begin{array}{l}\text { Antiparasitic antibacterial, antifungal, and antiviral properties. } \\
\text { Effective against pathogenic Mycobacterium tuberculosis and } \\
\text { Staphylococcus aureus, including methicillin-resistant } \\
\text { (MRSA) strains and biofilm infection of } S \text {. aureus. Contains } \\
\text { abietane diterpenes showing remarkable activity against } \\
\text { Plasmodium falciparum (malaria), Trypanosoma brucei } \\
\text { (sleeping sickness in animals). Nonspecific antiprotozoal } \\
\text { activity likely due to high cytotoxicity. Cancer prevention } \\
\text { properties }\end{array}$ \\
\hline $\begin{array}{l}\text { Epimedium davidii } \\
\text { (leaf) } \\
\text { [spring] herbaceous, perennial }\end{array}$ & $\begin{array}{l}\text { Enhancement of reproductive function (erectile, sperm count, } \\
\text { testosterone levels). Stress reduction and antidepressant } \\
\text { properties via downregulation of glucocorticoid receptor } \\
\text { activity and regulation of hippocampal neuroinflammation. } \\
\text { Anticancer activity, immunosuppressive action, and inhibition } \\
\text { of lymphocyte activation. Osteoprotective effect, } \\
\text { neuroprotective effect, cardiovascular protective effect, anti- } \\
\text { inflammation effect, and immunoprotective effect }\end{array}$ \\
\hline $\begin{array}{l}\text { Hedera nepalensis } \\
\text { (leaf) } \\
\text { [spring, autumn] evergreen } \\
\text { climber or creeper vine }\end{array}$ & $\begin{array}{l}\text { Purgative action, sweat-inducing and stimulant properties. } \\
\text { Used to treat skin diseases. Cancer preventative and cytotoxic } \\
\text { properties. Important folk medicine for the treatment of dia- } \\
\text { betes. Contains saponins and is toxic. Ingestion induces gas- } \\
\text { trointestinal nervous system disturbances }\end{array}$ \\
\hline $\begin{array}{l}\text { Ilex purpurea } \\
\text { (leaf) } \\
\text { [winter, spring, autumn] ever- } \\
\text { green tree }\end{array}$ & $\begin{array}{l}\text { One of the } 50 \text { fundamental herbs in Chinese medicine. } \\
\text { Antitumor properties. Used for treating burns, ulcers in the } \\
\text { lower extremities }\end{array}$ \\
\hline $\begin{array}{l}\text { Lespedeza bicolor } \\
\text { (leaf) } \\
\text { [spring, summer] deciduous } \\
\text { shrub }\end{array}$ & $\begin{array}{l}\text { Antioxidant, anticancer, and bactericidal activity. Tradition- } \\
\text { ally used for coughs and colds, kidney and urethra problems, } \\
\text { fever, headache, weakness, and dizziness. Contains flavo- } \\
\text { noids, alkaloids, terpenes, organic acids, and stigmasterols }\end{array}$ \\
\hline $\begin{array}{l}\text { Liquidambar formosana } \\
\text { (leaf) } \\
\text { [spring] deciduous tree }\end{array}$ & Treatment of cancerous growths \\
\hline $\begin{array}{l}\text { Litsea coreana } \\
\text { (leaf) } \\
\text { [year-round] evergreen tree }\end{array}$ & $\begin{array}{l}\text { Augments immunoglobulin M and G values and shows sig- } \\
\text { nificant inhibitory effects on pathogenic Bacillus anthracis, } \\
\text { Proteusbacillus vulgaris, Staphylococcus aureus, and Bacil- } \\
\text { lus subtilis. Anti-HSV-1 activity, anti-gastric carcinoma and } \\
\text { colon carcinoma HT-29 activity. Exhibits antibacterial, } \\
\text { hepatoprotective, hyperglycemic, anti-inflammatory, and } \\
\text { antioxidation activity. Contains polysaccharides, polyphe- } \\
\text { nols, essential oils, and numerous flavonoids }\end{array}$ \\
\hline $\begin{array}{l}\text { Loropetalum chinense } \\
\text { (leaf, stem) } \\
\text { [year-round] evergreen woody } \\
\text { shrub }\end{array}$ & $\begin{array}{l}\text { An external application to wounds. A treatment for coughing } \\
\text { in patients with tuberculosis, dysentery, and enteritis. Pro- } \\
\text { motes wound healing, possesses antibacterial activity. Anti- } \\
\text { inflammatory and antioxidant activity. Adjusts fat metabo- } \\
\text { lism. Contains antitumoral activity and protects from cardio- } \\
\text { vascular disease }\end{array}$ \\
\hline
\end{tabular}


Table 12.2 (continued)

\begin{tabular}{l|l}
\hline $\begin{array}{l}\text { Species (part ingested) [season } \\
\text { of use] form }\end{array}$ & $\begin{array}{l}\text { Medicinal properties (see text for references and further } \\
\text { details) }\end{array}$ \\
\hline $\begin{array}{l}\text { Millettia dielsiana } \\
\text { leaf) } \\
\text { [year-round] deciduous shrub }\end{array}$ & $\begin{array}{l}\text { Used for prevention of cardiovascular and cerebrovascular } \\
\text { disease. Significant antioxidant activity }\end{array}$ \\
\hline $\begin{array}{l}\text { Sargentodoxa cuneata } \\
\text { leaf) } \\
\text { [spring] deciduous climbing } \\
\text { shrub }\end{array}$ & $\begin{array}{l}\text { Anthelmintic (hookworm, roundworm, filariasis) and } \\
\text { antibacterial activity. Stem extracts exhibit anti-enterovirus } \\
\text { activity against anti-Coxsackie virus B3, Coxsackie virus B5, } \\
\text { Poliovirus I, Echovirus 9, and Echovirus 29. Also possess } \\
\text { antirheumatic, carminative, diuretic, and tonic properties. } \\
\text { Treatment for sores, amenorrhea, metrorrhagia (irregular } \\
\text { uterine bleeding), traumatic injuries, rheumatoid arthritis, and } \\
\text { anemia }\end{array}$ \\
\hline $\begin{array}{l}\text { Syzygium buxifolium } \\
\text { (leaf) } \\
\text { [year-round] evergreen shrub }\end{array}$ & $\begin{array}{l}\text { Taken as a febrifuge (reduce fever). Cooling effect when } \\
\text { rubbed on the bodies of smallpox patients }\end{array}$ \\
\hline $\begin{array}{l}\text { Vaccinium bracteatum } \\
\text { leaf) } \\
\text { [year-round] evergreen shrub }\end{array}$ & $\begin{array}{l}\text { Radical scavenging activity and protection against KBrO3- } \\
\text { mediated kidney damage. Anticancer and anti-inflammatory } \\
\text { activity. Contains isoorientin, orientin, vitexin, isovitexin, } \\
\text { isoquercitrin, quercetin-3-O- } \alpha \text {-L-rhamnoside, and chrysoeriol- } \\
\text { 7-O- } \beta \text {-D-glucopyranoside }\end{array}$ \\
\hline
\end{tabular}

\subsection{Future Research}

This study was designed to evaluate the potential for self-medication in Tibetan macaques. At present we cannot completely rule out the possibility that macaques consumed some or all of these plants described above only to meet some micronutrient deficiency, or that the amounts consumed were insufficient to bring about physiological change. However, the evidence presented in this chapter is compelling enough to warrant further research.

Where do we go from here? In order to demonstrate therapeutic self-medication, there are four basic requirements: (1) identify the disease or symptom(s) being treated, (2) distinguish the use of a therapeutic agent from that of everyday food items, (3) demonstrate a positive change in health condition following selfmedicative behavior, and (4) provide evidence for plant activity and or direct pharmacological analysis of compounds extracted from these therapeutic agents (Huffman 2010). The pharmacological activity reported here for 12 species is the first stage of fulfilling requirement (4). This suggests that ingesting these plants may elicit significant physiological benefit if ingested in sufficient amounts.

The broad spectrum of confirmed pharmacological activity reported here suggests several avenues of research to pursue in the future and reason to believe that Tibetan macaques self-medicate. Depending on the pharmacological activities of the plant in question, future work needs to attempt to directly link the context of use with the health status of the individual. This requires longitudinal investigation with attention to (1) seasonal influences (e.g., birth, mating, infection seasonality), (2) presence or 
absence of large-scale disruptive social influences likely to induce psychophysiological stress (e.g., troop fission or the death of a leader or principle caregiver), (3) reproductive state (e.g., pregnancy, estrus, reproductive history), and (4) age and health status. Monitoring of identified individuals representative of all age-sex classes, recording reinfection seasonality, infection intensity and behavioral indicators of poor health, weakened body condition, poor appetite, plant food selection patterns, etc. are required. These data will help to provide the necessary context of medicinal plant use to strengthen the case for self-medication in Tibetan macaques (e.g., see Huffman et al. 1996a, b; Huffman and Caton 2001; Alados and Huffman 2000; MacIntosh et al. 2011; Burgunder et al. 2017). Only recently has the effect of seasonal dietary change on micro- and mycobiota composition of Tibetan macaques been investigated (Sun et al. 2016, 2018).

In closing, it should be noted that there are still other medicinal properties in the medicinal diet that have not been discussed in detail. They need to be looked at more closely in the future. These include the possible roles of anti-inflammation, immunoprotection, antibiotic, antibacterial, and antiviral properties, in the passive protection or treatment of seasonal afflictions brought on by cold-damp or hot-humid weather conditions. Do troop members ingest these items more in some seasons than others? Noteworthy too about these understudied properties of the diet are the widespread anticancer (antitumoral), osteoprotective, cardiovascular protective, and neuroprotective effects. Do older members of the troop ingest items with these properties more often than younger ones?

In the aging Western society today, such diseases form the core of many of our health problems, and it has been argued that the cause of this is due to the change in our diets, shifting towards more processed foods and away from more natural food sources (Johns 1990). The properties of the Tibetan macaque diet may provide us with important insights into the long-term dietary strategy of primates occurring at the interface of food and medicine.

Acknowledgments MAH is grateful to the organizers of the International Symposium "Nonhuman Primates: Insights into Human Behavior and Society" held in Mt. Huangshan from July 21 to the 25, 2017, for being able to attend and exchange valuable scientific ideas and cultivate friendships and collaborations. This chapter is one result of that opportunity. MAH also thanks Yamato Tsuji and Massimo Bardi for their statistical advice and comments on the manuscript. BH SUN is very grateful to the Huangshan Garden Forest Bureau for their permission and support to his study. BH SUN also wishes to thank Xiaojuan Xu and Jayue Sun for their support during the writing of this manuscript. 


\section{Appendix: Plant Secondary Metabolites in Plant Items Ingested by Tibetan Macaques at Mt. Huangshan}

\begin{tabular}{l}
\hline Abietane (diterpenoid) \\
\hline Alkaloids \\
\hline Essential oils \\
\hline Flavonoids \\
\hline Icariin (prenylated flavonol glycoside) \\
\hline Icariside II (Baohuoside I) and Baohuoside II, III, V, VI \\
\hline Isoflavones \\
\hline i6-ethoxyca lpogonium isoflavone A, durmillone, ichthynone, jamaicin, toxicaro 1 \\
\hline Isoflavone, barbigerone, genistein \\
\hline Organic acids \\
\hline Polysaccharides \\
\hline Polyphenols \\
\hline Saponic glycosides (hederagenin) \\
\hline Stigmasterols \\
\hline Terpenes
\end{tabular}

\section{References}

Ahmed T, Khan A, Chandan P (2015) Photographic key for the identification of some plant of Indian Trans-Himalaya. Not Sci Biol 7:171-176

Alados CL, Huffman MA (2000) Fractal long-range correlations in behavioural sequences of wild chimpanzees: a non-invasive analytical tool for the evaluation of health. Ethology 106 (2): $105-116$

Alipayo D, Valdez R, Holechek JL et al (1992) Evaluation of microhistological analysis for determining ruminant diet botanical composition. J Range Manag 45:148-152

Altizer S, Dobson A, Hosseini P, Pascual M, Rohani P (2006) Seasonality and the dynamics of infectious diseases. Ecol Lett 9:467-484

Anonymous (1977) A barefoot doctors manual. Running Press, Philadelphia

Anthony RG, Smith NS (1974) Comparison of rumen and fecal analysis to describe deer diets. J Wildl Manag 38:535-540

Aureli F, Cords M, van Schaik CP (2002) Conflict resolution following aggression in gregarious animals: a predictive framework. Anim Behav 64:325-343

Bauer B, Sheeran LK, Matheson MD, Li J-H, Wagner RS (2014) Male Tibetan macaques' (Macaca thibetana) choice of infant bridging partners. Zool Res 35(3):222-230

Berger PJ, Sanders EH, Gardner PD, Negus NC (1977) Phenolic plant compounds functioning as reproductive inhibitors in Microtus montanus. Science 195:575-577

Berman CM, Ionica CS, Li J-H (2004) Dominance style among Macaca thibetana on Mt. Huangshan, China. Int J Primatol 25(6):1283-1312

Berman CM, Ionica CS, Li J-H (2007) Supportive and tolerant relationships among male Tibetan macaques at Huangshan, China. Behaviour 144:631-661 
Berry AK, Kaufer D (2015) Stress, social behavior, and resilience: insights from rodents. Neurobiol Stress 1:116-127

Brack M (1987) Agents transmissible from simians to man. Springer, Berlin

Brack M (2008) Oesophagostomiasis. EAZWV transmissible disease fact sheet no 116. https://c. ymcdn.com/sites/www.eazwv.org/resource/resmgr/Files/Transmissible_Diseases_Handbook/ Fact_Sheets/116_Oesophagostomiasis.pdf. Accessed 19 Jun 2018

Burgunder J, Pafco B, Petrelkova KJ, Modry D, Hashimoto C, MacIntosh AJJ (2017) Complexity in behavioral organization and strongylid infection among wild chimpanzees. Anim Behav 129:257-268

Carrai V, Borgognini-Tarli SM, Huffman MA et al (2003) Increase in tannin consumption by sifaka (Propithecus verreauxi verreauxi) females during the birth season: a case for self-medication in prosimians? Primates 44(1):61-66

Carter CS, Grippo AJ, Pournajafi-Nazarloo H, Ruscio MG, Porges SW (2008) Oxytocin, vasopressin and sociality. Prog Brain Res 170:331-336

Chang N, Luo Z, Li D et al (2017) Indigenous uses and pharmacological activity of traditional medicinal plants in Mount Taibai, China. Evid Based Complement Alternat Med 2017:8329817. https://doi.org/10.1155/2017/8329817

Chen M, Hao J, Yang Q et al (2014) Effects of icariin on reproductive functions in male rats. Molecules 19(7):09502-09514

Cousins D, Huffman MA (2002) Medicinal properties in the diet of gorillas - an ethnopharmacological evaluation. Afr Study Monogr 23:65-89

Duke JA, Ayensu ES (1985) Medicinal plants of China. Reference Publications, Algonac. isbn:0917256-20-4

Engel C (2002) Wild health. Houghton Mifflin, Boston

Etkin NL (1996) Medicinal cuisines: diet and ethnopharmacology. Int J Pharmacog 34(5):313-326

Etkin NL, Ross PJ (1983) Malaria, medicine, and meals: plant use among the Hausa and its impact on disease. In: Romanucci-Ross L, Moerman DE, Tancredi LR (eds) The anthropology of medicine: from culture to method. Praeger, New York, pp 231-259

Find Me A Cure (2018). https://findmeacure.com. Accessed 30 Apr 2018

Foitova I, Huffman MA, Wisnu N et al (2009) Parasites and their effect on orangutan health. In: Wish SA, Utami SS, Setia TM et al (eds) Orangutans-ecology, evolution, behavior and conservation. Oxford University Press, Oxford, pp 157-169

Forbey J, Harvey A, Huffman MA et al (2009) Exploitation of secondary metabolites by animals: a behavioral response to homeostatic challenges. Integr Comp Biol 49(3):314-328

Fraser ON, Stahl D, Aureli F (2008) Stress reduction through consolation in chimpanzees. PNAS 105(25):8557-8562

Freeland WJ, Janzen DH (1974) Strategies in herbivory by mammals: the role of plant secondary compounds. Am Nat 108(961):269-289

Frohne D, Pfänder JA (1984) Colour atlas of poisonous plants. Timber Press, Portland

Gadgil M, Bossert WH (1970) Life historical consequences of natural selection. Am Nat 104:1-24

Gan R-Y, Xu X-R, Song F-L et al (2010) Antioxidant activity and total phenolic content of medicinal plants associated with prevention and treatment of cardiovascular and cerebrovascular diseases. J Med Plant Res 4(22):2438-2444

Garey J, Markiewicz L, Gurpide E (1992) Estrogenic flowers, a stimulus for mating activity in female vervet monkeys. In: XIVth Congress of the International Primatological Society Abstracts, Strassbourg, p 210

Glander KE (1980) Reproduction and population growth in free-ranging mantled howling monkeys. Am J Phys Anthropol 53:25-36

Glander KE (1982) The impact of plant secondary compounds on primate feeding behavior. Yrbk Phys Anthropol 25:1-18

Gong T, Wang H-Q, Chen R-Y (2007) Isoflavones from vine stem of Millettia dielsiana. Zhongguo Zhong Yao Za Zhi 32(20):2138-2140 
Gong M-J, Han B, Wang S-M, Liang S-W (2016) Icariin reverses corticosterone- induced depression-like behavior, decrease in hippocampal brain-derived neurotrophic factor (BDNF) and metabolic network disturbances revealed by NMR-based metabonomics in rats. J Pharm Biomed Anal 123:63-73

Gotoh S (2000) Regional differences in the infection of wild Japanese macaques by gastrointestinal helminth parasites. Primates 41(3):291-298

Green MJ (1987) Diet composition and quality in Himalayan musk deer based on faecal analysis. J Wildl Manag 51:880-892

Guo J-P, Pang J, Wang X-W et al (2006) In vitro screening of traditionally used medicinal plants in China against enteroviruses. World J Gastroenterol 12(25):4078-4081

Hardy K, Buckley S, Collins MJ et al (2012) Neanderthal medics? Evidence for food, cooking and medicinal plants entrapped in dental calculus. Naturwissenschaften 99:617-626

Hardy K, Buckley S, Huffman MA (2013) Neanderthal self-medication in context. Antiquity 87:873-878

Herbpathy Data Base (2018). https://herbpathy.com. Accessed 27 Apr 2018

Hori T, Nakayama T, Tokura H, Hara F, Suzuki M (1977) Thermoregulation of Japanese macaque living in a snowy mountain area. Jpn J Physiol 27:305-319

Huffman MA (1997) Current evidence for self-medication in primates: a multidisciplinary perspective. Yrbk Phys Anthropol 40:171-200

Huffman MA (2002) Animal origins of herbal medicine. In: Fleurentin J, Pelt J-M, Mazars G (eds) From the sources of knowledge to the medicines of the future. IRD Editions, Paris, pp 31-42

Huffman MA (2003) Animal self-medication and ethno-medicine: exploration and exploitation of the medicinal properties of plants. Proc Nutr Soc 62:371-381

Huffman MA (2007) Animals as a source of medicinal wisdom in indigenous societies. In: Bekoff M (ed) Encyclopedia of human-animal relation, vol 2. Greenwood Publishing Group, Westport, CT, pp 434-441

Huffman MA (2010) Self-medication: passive prevention and active treatment. In: Breed MD, Moore J (eds) Encyclopedia of animal behavior, vol 3. Academic, Oxford, pp 125-131

Huffman MA (2011) Primate self-medication. In: Campbell C, Fuentes A, MacKinnon K et al (eds) Primates in perspective. University of Oxford Press, Oxford, pp 563-573

Huffman MA (2015) Chimpanzee self-medication: a historical perspective of the key findings. In: Nakamura M, Hosaka K, Itoh N, Zamma K (eds) Mahale chimpanzees-50 years of research. Cambridge University Press, Cambridge, pp 340-353

Huffman MA (2016) An ape's perspective on the origins of medicinal plant use in humans. In: Hardy K, Kubiak-Martens L (eds) Wild harvest: plants in the hominin and pre-agrarian human worlds. Oxbow Books, Oxford, pp 55-70

Huffman MA, Caton JM (2001) Self-induced increase of gut motility and the control of parasitic infections in wild chimpanzees. Int J Primatol 22:329-346

Huffman MA, MacIntosh AJJ (2012) Plant-food diet of the Arashiyama Japanese macaques and its potential medicinal value. In: Leca J-B, Huffman MA, Vasey PL (eds) The monkeys of Stormy Mountain: 60 years of primatological research on the Japanese macaques of Arashiyama. Cambridge University Press, Cambridge, pp 356-431

Huffman MA, Gotoh S, Izutsu D, Koshimizu K, Kalunde MS (1993) Further observations on the use of the medicinal plant, Vernonia amygdalina (Del) by a wild chimpanzee, its possible effect on parasite load, and its phytochemistry. Afr Stud Monogr 14(4):227-240

Huffman MA, Koshimizu K, Ohigashi H (1996a) Ethnobotany and zoopharmacognosy of Vernonia amygdalina, a medicinal plant used by humans and chimpanzees. In: Caligari PDS, Hind DJN (eds) Compositae: biology and utilization, vol 2. Royal Botanical Gardens, Kew, pp 351-360

Huffman MA, Page JE, Sukhdeo MVK et al (1996b) Leaf-swallowing by chimpanzees, a behavioral adaptation for the control of strongyle nematode infections. Int J Primatol 17(4):475-503

Huffman MA, Gotoh S, Turner LA et al (1997) Seasonal trends in intestinal nematode infection and medicinal plant use among chimpanzees in the Mahale Mountains National Park, Tanzania. Primates 38(2):111-125 
Huffman MA, Ohigashi H, Kawanaka M et al (1998) African great ape self-medication: a new paradigm for treating parasite disease with natural medicines? In: Ebizuka Y (ed) Towards natural medicine research in the 21st century. Elsevier Science BV, Amsterdam, pp 113-123

Jafri L, Saleem S, Kondrytuk TP et al (2016) Hedera nepalensis K. Koch: a novel source of natural cancer chemopreventive and anticancerous compounds. Phytother Res 30(3):447-453. https:// doi.org/10.1002/ptr.5546

Janzen DH (1978) Complications in interpreting the chemical defenses of trees against tropical arboreal plant-eating vertebrates. In: Montgomery GG (ed) The ecology of arboreal folivores. Smithsonian Institution Press, Washington, DC, pp 73-84

Jia X, Li P, Wan J, He C (2017) A review on phytochemical and pharmacological properties of Litsea coreana. Pharm Biol 55(1):1368-1374. https://doi.org/10.1080/13880209.2017. 1302482

Johns T (1990) With bitter herbs they shall eat it. University of Arizona Press, Tucson

Kelley EA, Jablonski NG, Chaplin G, Sussman RW, Kamilar JM (2016) Behavioral thermoregulation in Lemur catta: the significance of sunning and huddling behaviors. Am J Primatol 78:745-754

Krief S, Hladik CM, Haxaire C (2005) Ethnomedicinal and bioactive properties of the plants ingested by wild chimpanzees in Uganda. J Ethnopharmacol 101:1-15

Lambert JE (2011) Primate nutritional ecology, feeding biology and diet at ecological and evolutionary scales. In: Campbell CJ, Fuentes A, MacKinnon KC et al (eds) Primates in perspective. Oxford University Press, Oxford, pp 512-522

Landa P, Skalova L, Bousova I et al (2014) In vitro anti-proliferative and anti-inflammatory activity of leaf and fruit extracts from Vaccinium bracteatum Thunb. Pak J Pharm Sci 27(1):103-106

Lewis WH, Elvin-Lewis MPF (1977) Medical botany. Wiley, New York

Li J-H, Wang Q, Han D (1996) Fission in a free-ranging Tibetan macaque troop at Huangshan Mountain, China. Chin Sci Bull 41(16):1377-1381

Li J-H, Yin HB, Wang QS (2005) Seasonality of reproduction and sexual activity in female Tibetan macaques (Macaca thibetana) at Huangshan, China. Acta Zool Sin 51(3):365-375

Li J-H, Yin HB, Zhou L-Z (2007) Non-reproductive copulation behavior among Tibetan macaques at Huangshan, China. Primates 48:64-72

Li C, Li Q, Mei Q et al (2015) Pharmacological effects and pharmacokinetic properties of icariin, the major bioactive component in Herba Epimedii. Life Sci 126:57-68

Liu WJ, Xin ZC, Xin H et al (2005) Effects of icariin on erectile function and expression of nitric oxide synthase isoforms in castrated rats. Asian J Androl 7:381-388

Ma A, Qi S, Xu D et al (2004) Baohuoside-1, a novel immunosuppressive molecule, inhibits lymphocyte activation in vitro and in vivo. Transplantation 78(6):831-838

Ma H, He X, Yang Y et al (2011) The genus Epimedium, an ethnopharmacolgical and phytochemical review. J Ethnopharmacol 143:519-541

MacIntosh AJJ, Huffman MA (2010) Towards understanding the role of diet in host-parasite interactions in the case of Japanese macaques. In: Nakagawa F, Nakamichi M, Sugiura $\mathrm{H}$ (eds) The Japanese macaques. Springer, Tokyo, pp 323-344

MacIntosh AJJ, Hernandez A, Huffman MA (2010) Host age, sex, and reproductive seasonality affect nematode parasitism in wild Japanese macaques. Primates 51:353-364

MacIntosh JJJ, Alados CI, Huffman MA (2011) Fractal analysis of behavior in a wild primate: behavioural complexity in health and disease. J R Soc Interface 8(63):1497e1509

Mellado M, Foote RH, Rodriquez A et al (1991) Botanical composition and nutrient content of diets selected by goats grazing on desert grassland in northern Mexico. Small Rumin Res 6:141-150

Mothana RA, Al-Said MS, Al-Musayeib NM et al (2014) In vitro antiprotozoal activity of abietane diterpenoids isolated from Plenctranthus barbatus Andr. Int Mol Sci 15:8360-8371. http:// www.mdpi.com/1422-0067/15/5/8360. Accessed 27 Apr 2018

Mukherjee JR, Chelladurai V, Ronald J et al (2011) Do animals eat what we do? Observations on medicinal plants used by humans and animals of Mudanthurai Range, Tamil Nadu. In: Kala CP (ed) Medicinal plants and sustainable development. Nova Science, New York, pp 179-195 
Ndagurwa HGT (2012) Bark stripping by chacma baboons (Papio hamadryas ursinus) as a possible prophylactic measure in a pine plantation in eastern Zimbabwe. Afr J Ecol 51:164-167

Negre A, Tarnaud L, Roblot JF et al (2006) Plants consumed by Eulemur fulvus in Comoros Islands (Mayotte) and potential effects on intestinal parasites. Int J Primatol 27(6):1495-1517

Neto I, Faustino C, Rijo P (2015) Antimicrobial abietane diterpenoids against resistant bacteria and biofilms. In: Méndez-Vilas A (ed) The battle against microbial pathogens: basic science, technological advances and educational programs, Microbiology book series. Formatex Research Center, Badajoz

Ogawa H (1995a) Triadic male-female-infant relationships and bridging behavior among Tibetan macaques. Folia Primatol 64:153-157

Ogawa H (1995b) Recognition of social relationships in bridging behavior among Tibetan macaques (Macaca thibetana). Am J Primatol 35:305-310

Ohigashi H, Huffman MA, Izutsu D, Koshimizu K, Kawanaka M, Sugiyama H, Kirby GC, Warhurst DC, Allen D, Wright CW, Phillipson JD, Timmon-David P, Delmas F, Elias R, Balansard G (1994) Toward the chemical ecology of medicinal plant use in chimpanzees: the case of Vernonia amygdalina, a plant used by wild chimpanzees possibly for parasite-related diseases. J Chem Ecol 20(3):541-553

Oyeyemi IT, Akinlabi AA, Adewumi A, Aleshinloye AO, Oyeyemi OT (2018) Vernonia amygdlina: a folkloric herb with anthelmintic properties. Beni-Suef Univ J Basic Appl Sci 7:43-49

Pan Y, Wang F-M, Quang L-Q, Zhang D-M, Kong L-D (2010) Icariin attenuates chronic mild stress-induced dysregulation of the LHPA stress circuit in rats. Psychoneuroendocrinology 35:272-283

Petroni LM, Huffman MA, Rodriguez E (2016) Medicinal plants in the diet of woolly spider monkeys (Brachyteles arachnoides, E. Geoffroy, 1806) — a bio-rational for the search of new medicines for human use? Rev Bras Farm 27(2):135-142

Plants For A Future Data Base (1996-2012). https://pfaf.org/user/Default.aspx. Accessed 27 Apr 2018

Rosenthal GA, Berenbaum MR (1992) Herbivores: their interactions with secondary plant metabolites. Academic, San Diego

Rumble MA, Anderson SH (1993) Evaluating the microscopic fecal technique for estimating hard mast in turkey diets. USDA Forest Service Research Paper RM-310. https://www.fs.fed.us/rm/ pubs_rm/rm_rp310.pdf

Sadlier RM (1969) The ecology of reproduction in wild and domestic mammals. Methuer, London

Schenepel BL (2015) Provisioning and its effects on the social interactions of Tibetan Macaques (Macaca Thibetana) at Mt. Huangshan, China. All Master's Theses. 399. https:// digitalcommons.cwu.edu/etd/399

Simpson SJ, Sibly RM, Lee KP, Behmer ST, Raubenheimer D (2004) Optimal foraging when regulating intake of multiple nutrients. Anim Behav 68:1299-1311

Sparks DR, Malechek JC (1968) Estimating percentage dry weight in diets using a microscope technique. J Range Manage 21:264-265

Starker LA (1976) Phytoestrogens: adverse effects on reproduction in California quail. Science 191:98-100

Sun B, Wang X, Bernstein S, Huffman MA, Dong-Po Xia D-P, Gu Z, Chen R, Sheeran LK, Wagner RS, Li J (2016) Marked variation between winter and spring gut microbiota in free-ranging Tibetan Macaques (Macaca thibetana). Sci Rep 6:26035. https://doi.org/10.1038/srep26035

Sun B-H, Gu Z, Wang X, Huffman MA, Garber PA, Sheeran LK, Zhang D, Zhu Y, Xia D-P, Li J-H (2018) Season, age, and sex affect the fecal mycobiota of free-ranging Tibetan macaques (Macaca thibetana). Am J Primatol 80:e22880. https://doi.org/10.1002/ajp.22880

Takeshita RSC, Huffman MA, Bercovitch FB, Mouri K, Shimizu K (2013) The influence of age and season on fecal dehyroepiandrosterone-sulfate (DHEAS) concentrations in Japanese macaques (Macaca fuscata). Gen Comp Endocrinol 19:39-43 
Takeshita RSC, Bercovitch FB, Huffman MA, Mouri K, Garcia C et al (2014) Environmental, biological, and social factors influencing fecal adrenal steroid concentrations in female Japanese macaques (Macaca fuscata). Am J Primatol 76:1084-1093

Takeshita RSC, Bercovitch FB, Kinoshita K, Huffman MA (2018) Beneficial effects of hot springs bathing on stress levels in Japanese macaques. Primates 59(3):215-225

Ullah S (2017) Methanolic extract from Lespedeza bicolor: potential candidates for natural antioxidant and anticancer agent. J Tradit Chin Med 37(4):444-451

Usher G (1974) A dictionary of plants used by man. Macmillan, London

Wallis J (1992) Socioenvironmental effects on timing of first postpartum cycles in chimpanzees. In: Nishida T, McGrew WC, Marler P, Pickford M, de Waal F (eds) Topics in primatology, Human origins, vol 1. University of Tokyo Press, Tokyo, pp 119-130

Wallis J (1994) Socioenvironmental effects on full anogenital swellings in adolescent female chimpanzees. In: Roeder JJ, Thierry B, Anderson JR, Herrenschmidt N (eds) Current primatology, Social development, learning and behavior, vol 2. University of Louis Pasteur, Strasbourg, pp 25-32

Wallis J (1995) Seasonal influence on reproduction in chimpanzees of Gombe National Park. Int J Primatol 16:435-451

Wallis J (1997) A survey of reproductive parameters in the free-ranging chimpanzees of Gombe National Park. J Reprod Fertil 109:297-307

Wasserman MD, Chapman CA, Milton K, Gogarten JF, Wittwer DJ, Zeigler TE (2012) Estrogenic plant consumption predicts red colobus monkey hormonal state and behavior. Horm Behav 62:553-562

Whitten PL (1983) Flowers, fertility and females. Abstract. Am J Phys Anthropol 60:269-270

Wooddell LJ, Kaburu SSK, Rosenberg KL et al (2016) Matrilineal behavioral and physiological changes following the removal of a non-alpha matriarch in rhesus macaques. PLoS One 11(6): e0157108

World Agroforestry Data Base (2018). http://www.worldagroforestry.org/treedb/. Accessed 27 Apr 2018

Wu J, Du J, Xu C, Le J, Xu Y, Liu B, Dong J (2011) Icariin attenuates social defeat-induced downregulation of glucocorticoid receptor in mice. Pharmacol Biochem Behav 98:273-278

Xia D-P, Li J-H, Zhu Y, Sun B-H, Sheeran LK, Matheson MD (2010) Seasonal variation and synchronization sexual behaviors in free-ranging male macaques (Macaca thibetana) at Huangshan, China. Zool Res 31(5):509-515

Xia D-P, Wang X, Zhang Q-X, Sun B-H, Sun L, Sheeran LK, Li J-H (2018) Progesterone levels in seasonally breeding, free-ranging male Macaca thibetana. Mamm Res 63:99-106

Yeung H-C (1985) Handbook of Chinese herbs and formulas. Institute of Chinese Medicine, Los Angeles

You S-Y, Yin H-B, Zhang S-Z et al (2013) Food habits of Macaca thibetana. China J Biol 30 (5):64-67

Zhang P, Watanabe K (2007) Extra-large cluster formation by Japanese macaques (Macaca fuscata) on Shodoshima Island, Central Japan, and related factors. Am J Primatol 69:1119-1130

Zhang J, Chu C-J, Li X-L et al (2014a) Isolation and identification of antioxidant compounds in Vaccinium bracteatum Thunb. by UHPLC-Q-TOF LC/MS and their kidney damage protection. J Funct Foods 11:62-10

Zhang Y, Ren F-X, Yang Y et al (2014b) Chemical constituents and biological activities of Loropetalum chinense and Loropetalum chinense var. rubrum: research advances. J Int Pharm Res 41(3):307-312

Zhao Q-K (1993) Sexual behavior of Tibetan macaques at Mt. Emei, China. Primates 34 (4):431-444

Zhou H-T, Cao J-M, Lin Q et al (2013) Effect of Epimedium davidii on testosterone content, substance metabolism an exercise capacity in rats receiving exercise training. Chin Pharm $\mathrm{J} 48$ (1):25-29 
Zhou J, Wang Y-S, Wu Z-G (2014) Study of medicinal value of Loropetalum chinense. CJTCMP 29(7):2283-2286

Zhu Y, Ji H, Li J-H, Xia D-P, Sun B-H, Xu Y-R, Kyes RC (2012) First report of the wild Tibetan macaque (Macaca thibetana) as a new primate host of Gongylonema pulchrum with high incidence in China. J Anim Vet Adv 11(24):4514-4518

Open Access This chapter is licensed under the terms of the Creative Commons Attribution 4.0 International License (http://creativecommons.org/licenses/by/4.0/), which permits use, sharing, adaptation, distribution and reproduction in any medium or format, as long as you give appropriate credit to the original author(s) and the source, provide a link to the Creative Commons licence and indicate if changes were made.

The images or other third party material in this chapter are included in the chapter's Creative Commons licence, unless indicated otherwise in a credit line to the material. If material is not included in the chapter's Creative Commons licence and your intended use is not permitted by statutory regulation or exceeds the permitted use, you will need to obtain permission directly from the copyright holder. 